\title{
Utilization of Shop House Corridor in Medan
}

\author{
Wahyuni Zahrah, Shella Lie \\ Department of Architecture, Faculty of Engineering, \\ University of Sumatera Utara, Indonesia \\ wahyuni.zahrah@gmail.com
}

\begin{abstract}
The paper means to explore how people use and perceive the shop house corridor as the most built environment found in Medan, Indonesia. The research observed the adaptation and or adjustment pattern of people in their built environment through behavioral mapping. The study did an interview with users of the space to get people perception of the built environment quality. The result indicates that people used space mostly for market activities, in particular for the movable street vendor, besides the circulation path function. The users make some adaptation to fit their needs. They "divided" urban space and mark their territory based on the "unwritten agreement" and tolerance.
\end{abstract}

Keywords: Urban corridor; built environment; environment behavior; Medan

eISSN 2398-4295 @ 2018. The Authors. Published for AMER ABRA cE-Bs by e-International Publishing House, Ltd., UK. This is an open-access article under the CC BY-NC-ND license (http://creativecommons.org/licenses/bync-nd/4.0/). Peer-review under responsibility of AMER (Association of Malaysian Environment-Behaviour Researchers), ABRA (Association of Behavioural Researchers on Asians) and CE-Bs (Centre for EnvironmentBehaviour Studies), Faculty of Architecture, Planning \& Surveying, Universiti Teknologi MARA, Malaysia.

DOI: http://dx.doi.org/10.21834/ajbes.v3i13.157 


\subsection{Introduction}

\subsection{Background and issues}

The most built environment that developed in Medan in the last ten years is the shop houses area. While the issue of the shophouse in Malacca (Wan Ismail, 2012) and Singapore regarding the heritage conservation concern, in Medan, shop houses is a product of land and building efficiency for commercial needs. The most activities occur in this area is the informal sector, known as street vendors or 'pedagang kaki lima- PKL' in the local term. The PKL spread out over all city's space, from a neighborhood environment to the commercial districts; from a narrow street to the large arterial road. Due to a lack of municipality's control, the PKL arranges the urban spaces by themselves in their own way. The product of such 'spontaneous space' express a messy-disorder-untidy-dirty place. However, people have been living their life in that kind of space for years. In Medan and many Indonesia's cities, the number of built environment that created by this 'common' people is larger than those that designed by architects or urban designers. It can be said that many parts of the city are the product of community-own design. If the design activity has a noble aim to accommodate human civilization, it is necessary to understand how people create such urban space.

\subsection{Objective and purpose}

The research means to explore the way people use urban space, particularly in shophouses corridors in Medan. First, the study identifies the quality of the urban space. Next, the study investigates the activities goes on, people involved, time of using and the adaptation and or adjustment of the users. The research can contribute to enriching the reference in studies about man-environment-behavior, specifically for the urban spaces that have a lack of the professional role.

\subsection{Literature Review}

Altman dan Chemers (1980: 4), in their book Culture and Environment, define built environment as follow: "built environment refers to the results of people's alteration of environment - for example, homes, cities, communities, and farms. " The definition highlights the human alteration in changing the environment. The emphasis on human's role in the built environment also argued by Lawrence dan Low (1990). They said that built environment "refers to the broadest sense of any physical alteration of the natural environment through construction by human ". They use the term 'built environment' for all environment modified by human, because "the term architecture tends to relate with a special expert, usually monumental and becomes the civilization's nature. Thus, all built environment basically is a product of design, with or without architect (Rapoport, 1987).

Urban space is a part of built environment that grows fast, mainly in the developing countries, including Indonesia. Unfortunately, the city government does not always respond it effectively. There are not an adequate planning, applying and controlling the dynamics of the urban area. Consequently, the urban development run in a sporadic and unstructured way. The large scale of this escalation contributes significantly to the whole of the urban image and life 
There are two kinds of design tradition. The first, a 'grand design' tradition that relates to the involvement of the architects. The second, a 'folk tradition', that associated with the primitive or vernacular people tradition. It is a fact that the built environment as a folk tradition product is larger than the grand design. Thus, that kind of design is significant in shaping built environment (Rapoport, 1969).

A design activity is a process of choosing alternatives. The perceived world merges with an ideal image and this unification create the built environment's expression. Because of various cultures and traditions, the quality of the environments become complex. However, the variables cannot be determined, but should be explored (Rapoport, 1980). Thus, it is necessary to search the variables because no a fix standard applied to all condition of the place and people. The various cultures made various people's perspective and practice in the urban life (Segun, 2012).

In the design process of the built environment, there are some concerns for the perception of environment problems, the opportunity, ideal solution, and the acceptance or neglection. The environmental perception affects how people are receiving and knowing the actual environment (Rapoport, 1980). The interaction between individual and object constructs the perception. If it in an optimum limit, the individual is in the homeostatic condition. Thus, the circumstance is balancing. The human usually tends to keep this state because it improves a happy feeling. On the contrary, if the object is perceived exceed the optimum limit (e.g. too big, too cold, too strange), the individual becomes stress. The pressure becomes multiplied, so the individual should make a 'coping' to the environment or adjust the environment to fit his or her needs. The perception scheme of Bell et al. (1977, in Sarwono, 1992) shows that the utilization of built environment depends on the individual perception. The perception causes the adaptation - human change their behavior to fit with the environment, or adjustment - people change their environment to fit their needs and behavior (Sarwono, 1992).

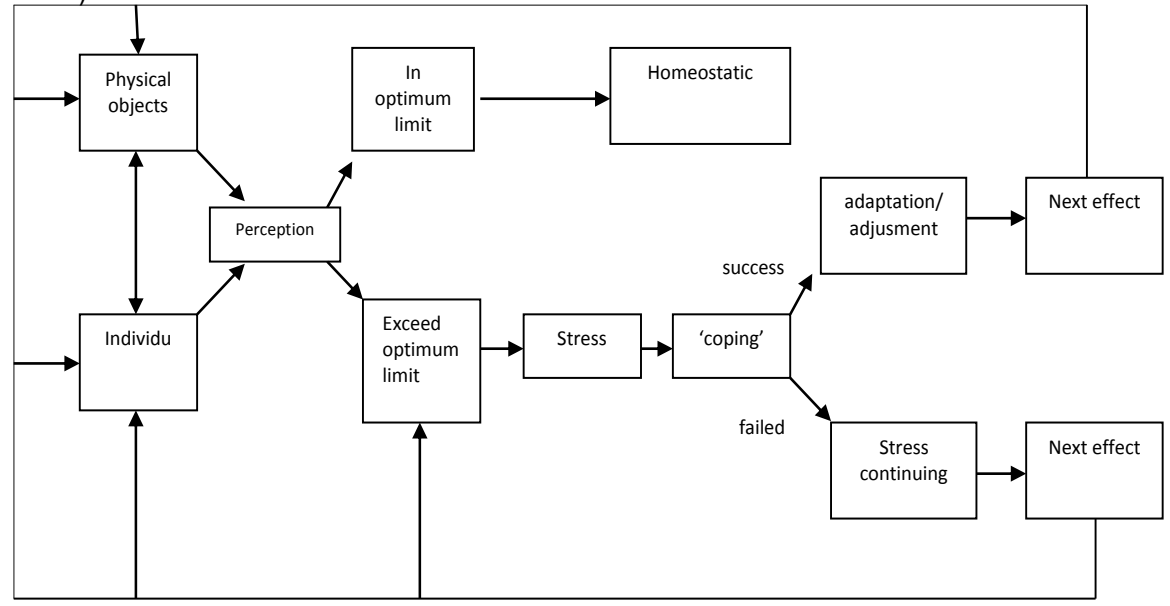

Figure 1. The perception scheme according to Bell et al (1977).

Source: Sarwono (1992) 


\subsection{Methodology}

\subsection{Study location and respondents}

The study took place in a shophouses district in the center of Medan, known as 'Pajak Bulan.' 'Pajak,' in the local term, is a marketplace. The marketplace occupies the street space in Jalan Sutomo Corridor and Jalan Martinus Lubis with Jalan Sei Kera dan Jalan Seram as the boundaries (Figure 2). The respondents were 105 merchants, customers, and the local residents. The data collected on 2014.

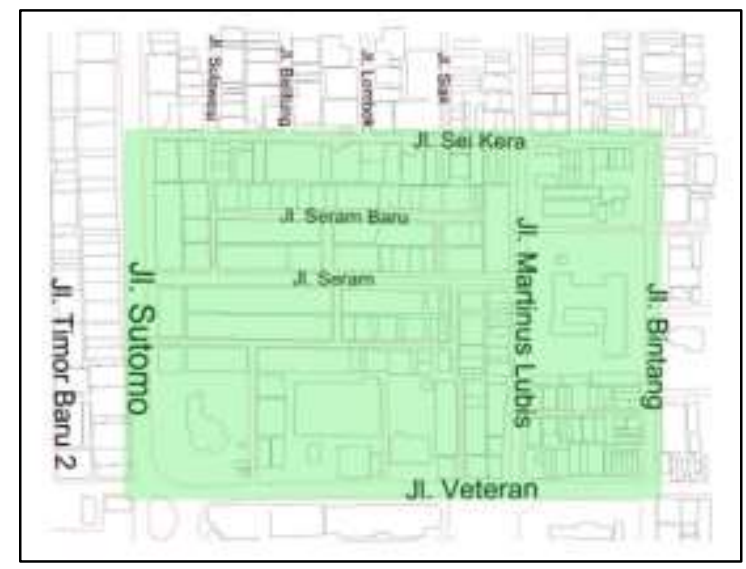

Figure 2. The study area

\subsection{Variables and data collecting}

The research variables are the setting, activity and people perception with the setting. The setting is an urban space where people run their operations. The study mapped the condition of the setting through a field survey, consisted of the dimension of streetscape, accessibility, parking lot and street furniture. The surveyors recorded the activity through a behavioral mapping that carried out in several time brackets: $00.00-02.00,05.00-07.00,10.00-$ 12.00 and $15.00-17.00$. There were two kinds of behavioral method conducted, namely person-centered mapping and place centered mapping. The person-centered mapping documented the activities chronologically. The documentation showed the step by step people occupied the urban space. The place-centered mapping observed the activity pattern in a whole study area in a time bracket. The survey collected people perception with the quality of space through a set of questionnaire. The respondents involved were those who were in the study area and agreed to participate in the study. The questionnaire consisted of the subjects about respondent's background and the evaluation of the quality of space. The measuring of people perception used the five scale Likert Scale from 5 for 'excellent' to 1 for 'terrible'.

\subsection{Results and Discussions}

\subsection{Study Area}

The shophouses corridor are located in a part of the center of commercial districts in Medan. 
The area has been an activity center since Dutch Colonial era. The zone consist of shophouses typology, in Medan known as 'rumah toko' or 'ruko'. The study observed two corridors, namely Jalan Sutomo and Jalan Martinus Lubis (the former Jalan Bulan). The observation area was the streetscape bounded by the shophouses rows on the two sides of the corridor. This space actually is a kind of public space that functioned as a marketplace. This is not a permanent facilities since there are no permanents buildings for the market. However, this is not a temporary function since the utilization has been existing for years. The activities show that the place is a kind of temporary free market, but the transaction seems like a permanent utility because of the extensive time period of using. However, there are no facilities as the common marketplace - e.g. the market kiosks, public toilets, parking lot, and the 'building' for sheltering the activities.

\subsection{Physical setting}

Jalan Sutomo and Jalan Martinus Lubis corridors were two main streets in the center of Medan. Jalan Sutomo was a 15 meters width arterial road connecting West and East part of Medan. Jalan Martinus Lubis is a 10 meters width collector street. The primary function of the two corridors are the main circulation path, but the marketplace activities fill the space in a certain time. The buildings in the area are shop houses typology with mostly mix-use function. It is a shop zone at the lower level and a housing area at the upper level. The grid configuration of the shop houses district makes it an accessible place. The visitors can reach the corridor from all direction by many transportation modes, either public transport or private vehicle.

\subsection{Utilization of urban space}

The duration of use of Jalan Sutomo for the marketplace was shorter than Jalan Martinus Lubis. This arterial corridor was busy for public use only in the midnight until early morning. The kind of transaction was a fresh market wholesale. Many kinds of vegetables were offered in the area at a time range of $00.00-05.00$ o'clock in the early mornings. At that moment, there were a very slight number of vehicles passed through, except those that related to the market function. The customers of the wholesale market were the frequent buyers of the retail marketplace merchants. Since some of them ordered the stuff by phone, the Sutomo corridor was more a place for picking up the order, downloading and uploading it to the vehicle box. Figure 4 showed that they occupied the entire street-space.

Figure 3 represents the person-centered mapping of a merchant in Jalan Sutomo. The picture illustrated that the merchant just chosen a place, marked it with his or her stuffs, used it as a temporal territory, and then the trading activity was going on. People used the urban space with no particular rule and no specific tools. A space of $32 \mathrm{~m} 2$ was occupied by two to three merchants. There was no a 'formal' shape. The merchants took the space side by side without any strict order. At 07.00 o'clock the marketplace finished, and the street became functioning as a circulation path.

In the afternoon, at the time range of $15.00-17.00$ the other informal market again occupied Jalan Sutomo. They sold the secondary stuff, known as "Pasar Loak' in the local term. The secondary market took place on the sidewalk of $1-1.5 \mathrm{~m} 2$ wide. They were 
concentrated in the conjunction of Jalan Sutomo - Jalan Veteran. The urban space became crowded again. By the absence of an adequate parking lot, customers put their cars or motorbike in the street periphery. The condition made the street so crowded: the moving cars and other transportation modes, the cars and the other vehicles that parked in the street border, the merchants, the customers. The place centered mapping in figure 5 showed this situation.

Meanwhile, at Jalan Martinus Lubis also occurred the retail market activities, started at 02.00 in the early morning. The peak activity was going on at $05.00-07.00$ in the morning. Beside the 'free market' the shophouse around the street also sold many kinds of foodstuff, such as rice, sugar, flour, cooking oil; all goods that complemented each other with fresh market sold on the street. This situation made the area very active and busy. Many people came here buying daily foodstuff they needed. It showed that there was a symbiosis mutualism between free market vendors and the permanent store. The facilities in the shophouses, such as the toilet, was used by the merchants.

The different of the type of transaction (wholesale and retail) caused the different way in utilizing the space. In Jalan Sutomo, the merchants did not need many kinds of equipment, but in Jalan Martinus, the vendor had to provide a wood table and or an umbrella or tent for sheltering their area (Figure 3). It was because, in the retailing market, the transaction took a longer duration than the wholesale. In this case, the market was going on until $11.00 \mathrm{am}$. The equipment was mostly portable, so it did not change the 'original' condition of the street. However, when the market finished, the merchants left their kit on the street periphery. They put it in front of the shophouse under shophouse owner permission. The merchants entrusted it to the shophouse owner around their area and paid the cost for it by their own agreement. At $11.00 \mathrm{am}$ the market activities were becoming inactive. At $15.00 \mathrm{pm}$, the street was functioning again as a circulation path.

The users of these corridors mostly had a good perception of the security and accessibility of the place but gave the lower score for the cleanliness and facilities. With this condition, people still used the corridor so intensive, either as a marketplace and circulation path. The fact showed that the urban space was active, many people came to the place every day. Some reasons they mentioned to visit the market were the affordable commodity (60\%) and the close range from their home $(23 \%)$. In Jalan Sutomo, there were not interaction between merchants and the buildings owner around, but in Jalan Martinus Lubis indicated an engagement among people. The free-market merchants were familiar with the buildings owner. They took a mutual relationship. Similarly, between free market merchants and customers also recognized each other $(86 \%)$. From this point of view, the corridor was a success and livable community space.

These two corridors demonstrated that people assumed the urban space could be occupied by the private interest; being a marketplace in this case. In the other side, some of urban community seems accepted this. They kept coming to the place and thought that the place supplied their needs. Thus, the street became a 'public facility'. There was no quality concern for this needs. The most important aspects the low-priced commodity. The other factor was the easy-access space. These considerations were the choice they made. Referred to the choice model in designing built environment that proposed by Rapoprt (1980), 
the economical reason seemed the most motive that people chose.

The study indicated that people tended to maintain this circumstance. They survived in this condition by keeping the space as it was without any physical changing. There was no permanent adjustment. They mostly made an adaptation instead of adjustment or modification of the existing setting. They used portable equipment, they wore a coat in the rainy days and survived with this. From the environment behavior approach, they were in a homeostatic-circumstant (Bell, 1977).

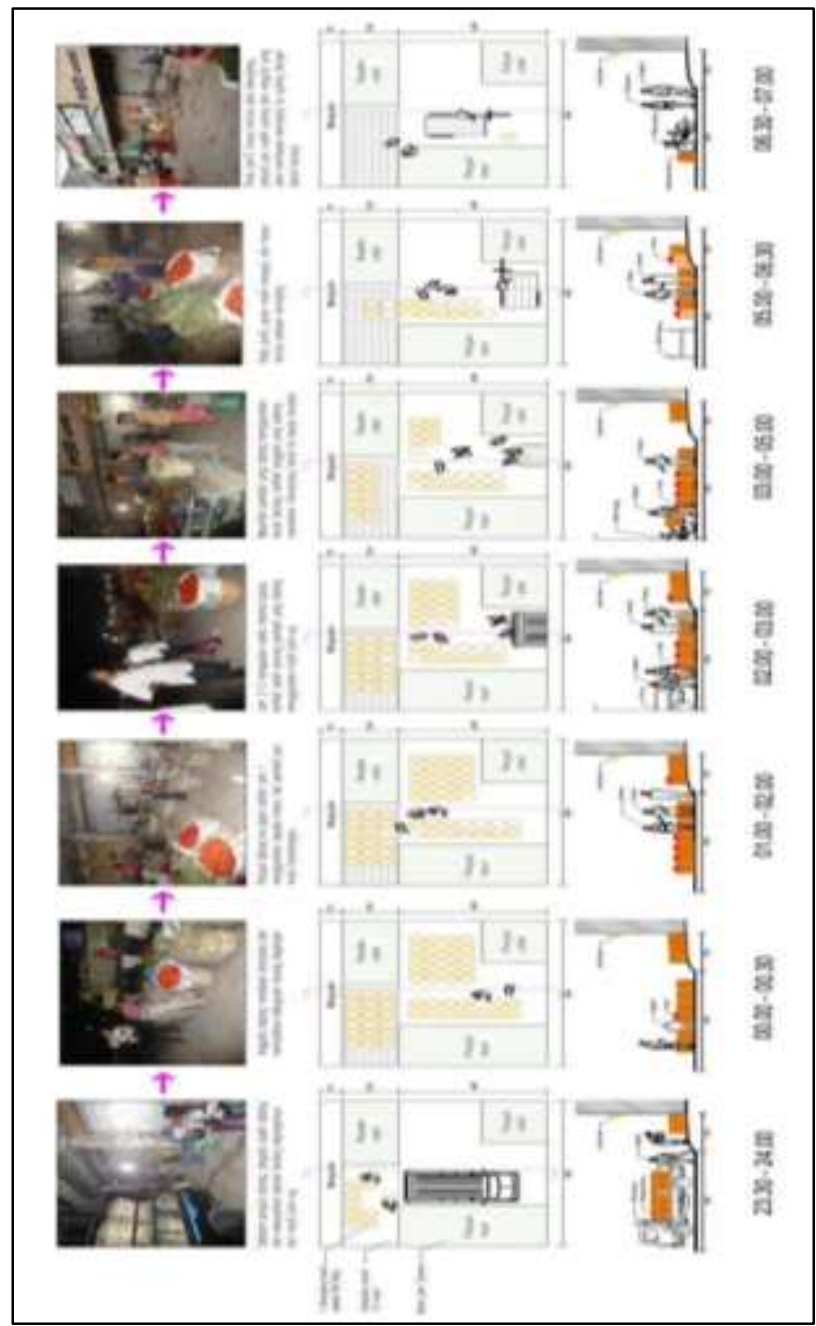

Figure 3. Person-centered mapping of utilization of urban space at Jalan Sutomo from $23.30-07.00$ 


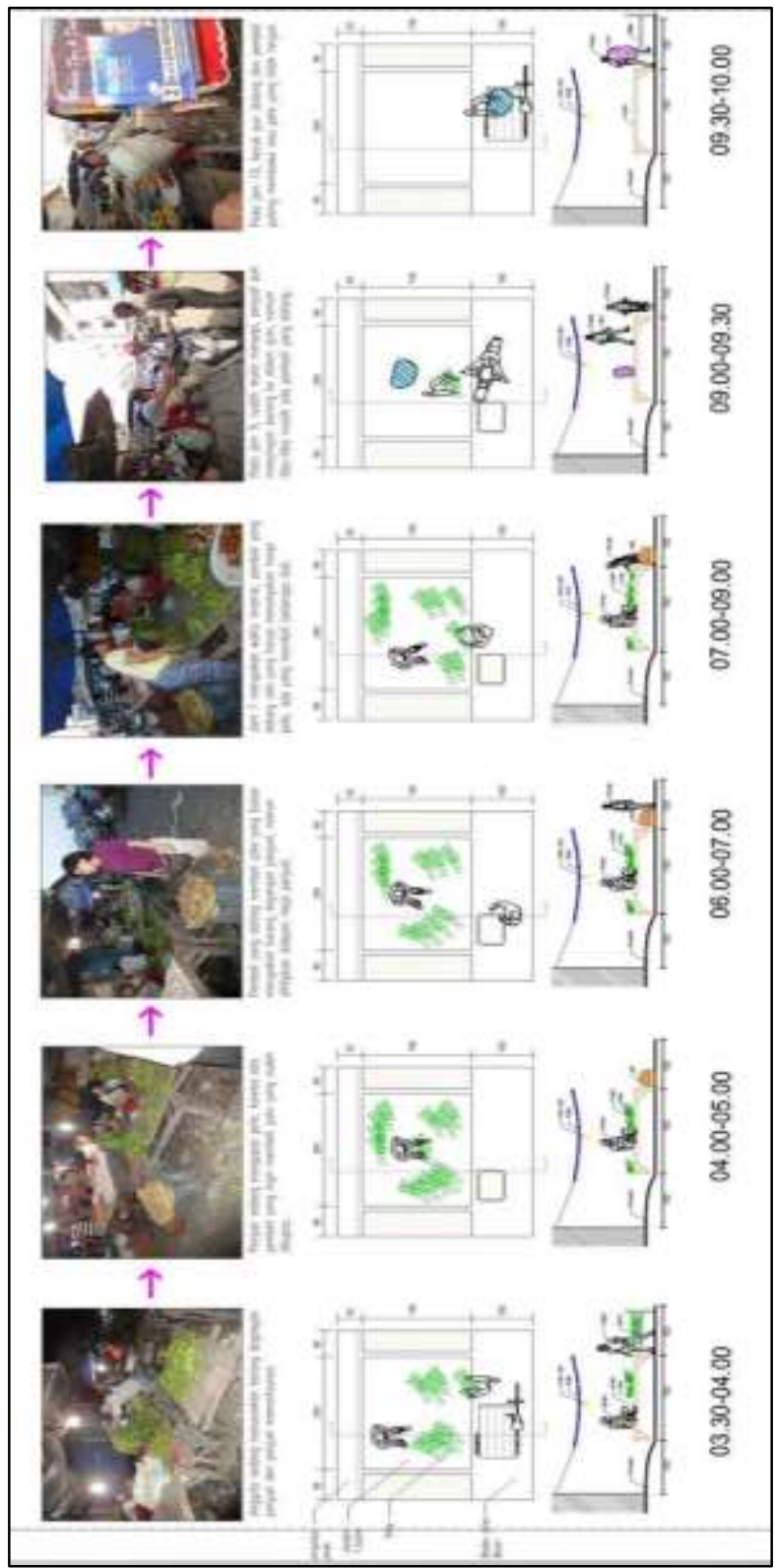

Figure 4. Person centered mapping of utilisation of urban space at Jalan Martinus Lubis from 03.30 10.00 
Zahrah, W., \& Lie, S. / Asian Journal of Behavioural Studies (AjBeS), 3(13) Sep / Oct 2018 (p. 201-212)

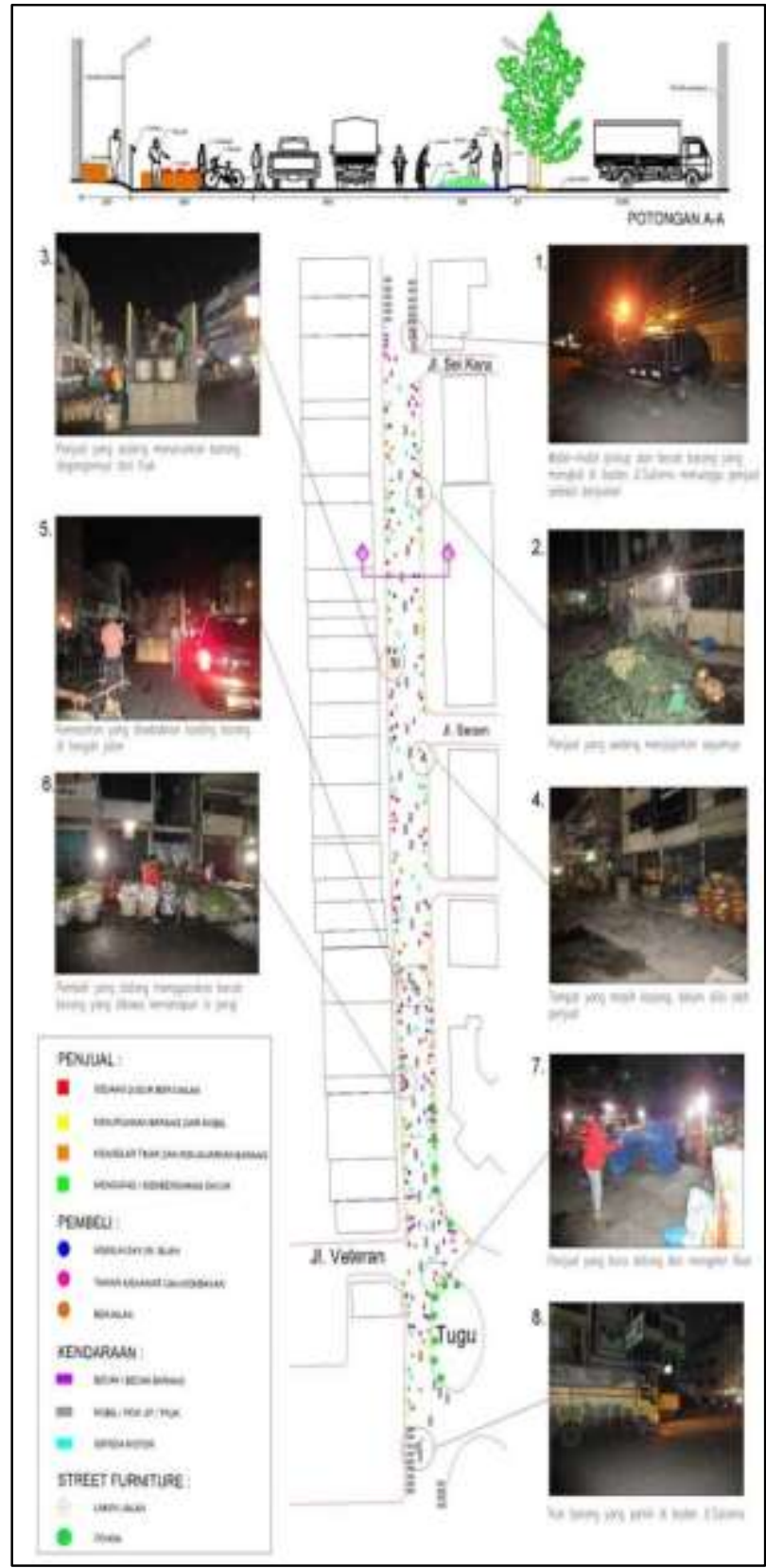

Figure 5. Place centered mapping of activities at Jalan Sutomo at early morning 


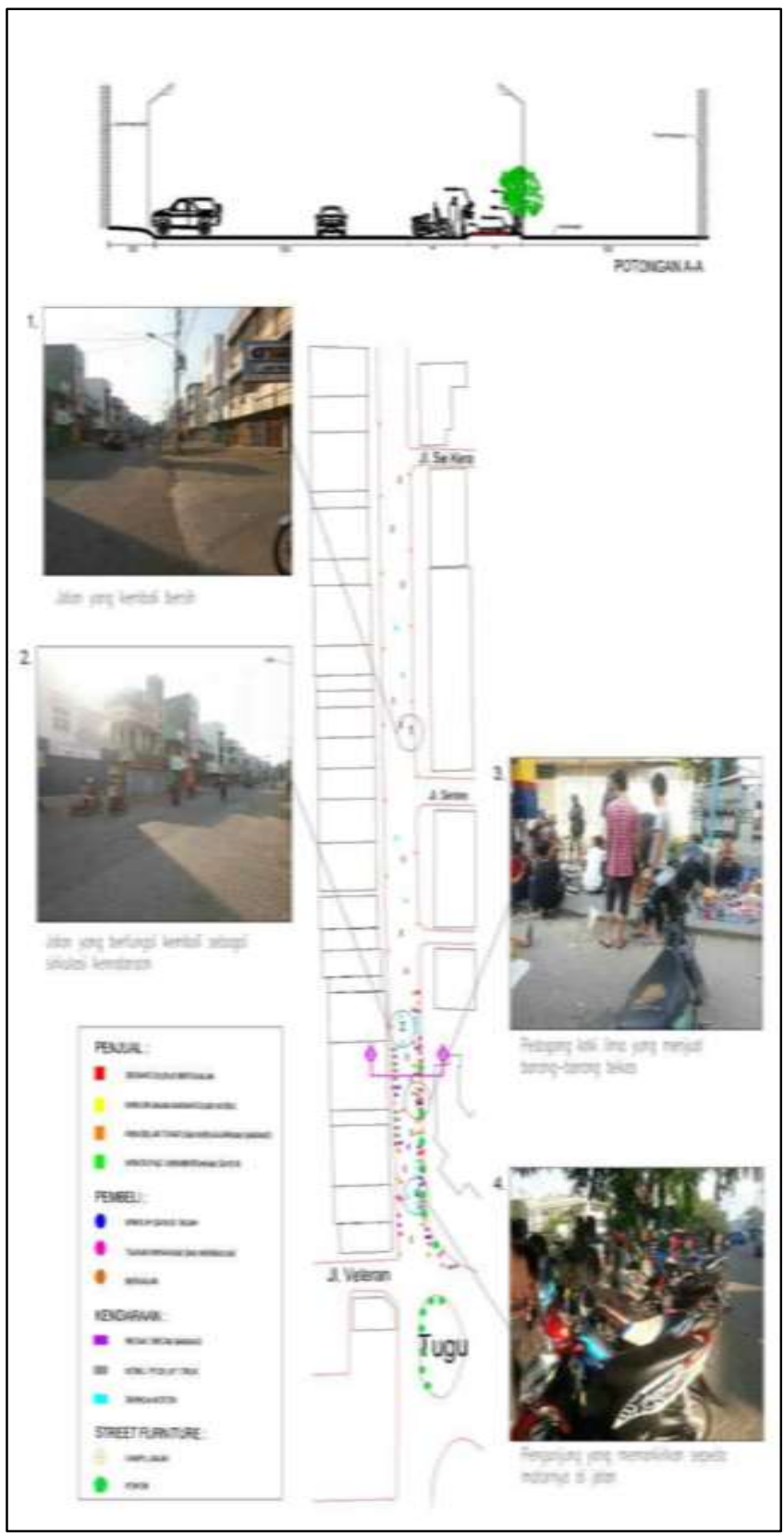

Figure 6. Place centered mapping of activities at Jalan Sutomo at early afternoon (right) 
Zahrah, W., \& Lie, S. / Asian Journal of Behavioural Studies (AjBeS), 3(13) Sep / Oct 2018 (p. 201-212)

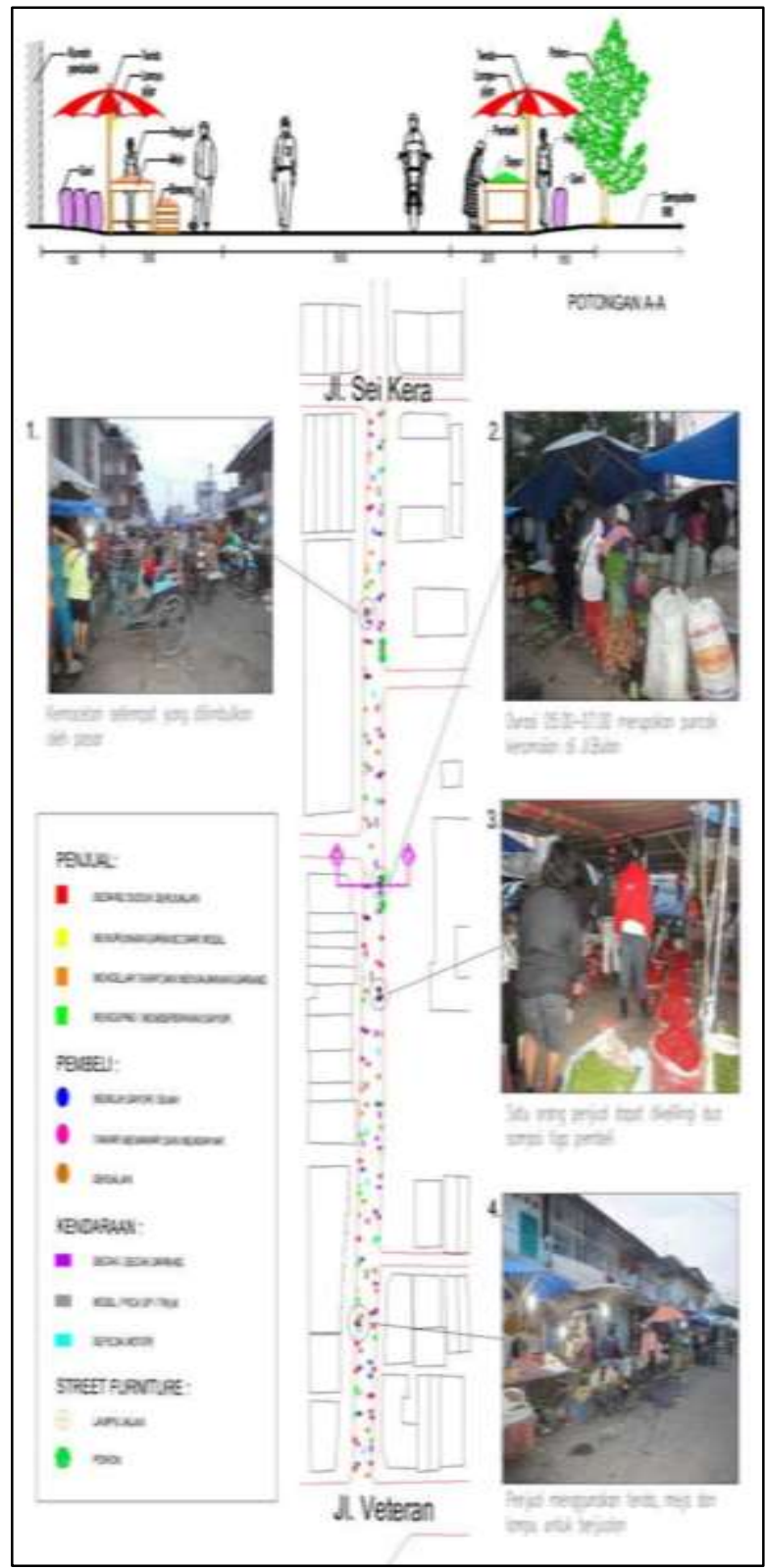

Figure 7. Place centered mapping of activities at Jalan Martinus Lubis in the morning 


\subsection{Conclusion}

The research showed that public space in the urban area of Medan, in this case, the shop houses area, became a private interest. However, since the place contributed to the public needs, it has been used for many years with all its limitation of quality and facility. The people seemed accepted the place. They kept coming to buy their daily needs. The process and the arrangement of the area were going on in a spontaneous way without any professional or government role. The urban space had a poor quality but showed an active activity. As long as it did not cause a conflict of interest between the other people needs, this kind of space need to be enhanced, particularly the facilities (e.g. cleanliness and parking lot). However, the spread out of this 'free occupation' over the city's areas, would interfere public needs for a comfort and fluent circulation path. The economic reason for occupying this kind of space should be responded by developing an affordable and well management marketplace. The government has to pay more attention to the informal sector. However, the research has a limitation in just exploring the utilization of space by people who use and have interest with the place. The next study has to observe and analyze the perception of the other users, such as street and building users around space.

\section{References}

Altman, Irwin dan Chemers, Martin, (1980). Culture and Environment, Monterey, California: Books/Cole Publishing Company

Horayangkura, Vimolsiddhi (2012). Incorporating environment-behavior knowledge into the design process: an elusive challenge for architects in the 21st century. Procedia - Social and Behavioral Sciences 50 ( 2012 ) 30 - 41

Lawrence, Denise L. and Low , Setha M. (1990). The Built Environment and Spatial Form. Annual Review of Anthropology Vol. 19, (1990), pp. 453-505.

Rapoport, Amos, (1969). House, Form and Culture, Englewood Cliffs, NJ : Prentice-Hall, Inc.

Rapoport, Amos, (1980). Human Aspect of Urban Form, Oxford: Pergamon Press

Sarwono, Sarlito Wirawan, 1992, Psikologi Lingkungan, Jakarta : Gramedia dan Program Pascasarjana Program Studi Psikologi, Universitas Indonnesia

Segun, Okunola (2012). Behavioral outcomes of culture and socio-economic status on urban residential morphology: a case study of Lagos, Procedia - Social and Behavioral Sciences 50 ( 2012 ) 294 - 306

Wan Ismail , Wan Hashimah, (2012). Users and the survival of the shop houses in the historic city of Malacca, Procedia - Social and Behavioral Sciences 42. ( 2012 ) 443 - 450 